\title{
Identyfikacja małych zlewni podatnych na formowanie gwałtownych wezbrań (na przykładzie Pogórza Dynowskiego, Strzyżowskiego i Przemyskiego)
}

\author{
The identification of small drainage basins prone to flash-flood creation \\ (as exemplified by the Dynów, Strzyżów and Przemyśl foothill areas)
}

\section{TOMASZ BRYNDAL}

Instytut Geografii, Uniwersytet Pedagogiczny w Krakowie, 30-084 Kraków, ul. Podchorążych 2; tbryndal@ap.krakow.pl

Zarys treści. Zaprezentowano procedurę wyodrębniania małych zlewni podatnych na formowanie gwałtownych wezbrań, spowodowanych przez krótkotrwałe intensywne opady deszczu. Zlewnie karpackie, w których wystąpiły lokalne powodzie, opisano za pomocą licznych charakterystyk fizjograficznych, dobranych w taki sposób, aby obejmowały cechy znaczące w formowaniu gwałtownego wezbrania. Ustalono, że takie cechy jak: powierzchnia zlewni, nachylenie stoków, spadek dna doliny głównej, struktura użytkowania, właściwości fizyczne gleb oraz układ i gęstość sieci rzecznej mają wpływ na transformację opadu w odpływ, a w efekcie na podatność zlewni na formowanie gwałtownych fal wezbraniowych. Na podstawie wyników analizy wielowymiarowej wydzielono typy zlewni podatnych na formowanie gwałtownych wezbrań, wykorzystane jako wzorce przy identyfikacji zlewni o podobnych właściwościach na terenie Pogórza Strzyżowskiego, Dynowskiego i Przemyskiego. W wydzielonych zlewniach należy w przyszłości wyznaczyć granice obszarów zagrożonych gwałtownymi wezbraniami oraz prowadzić działania, które pozwolą ograniczyć straty jakie mogą spowodować te zjawiska.

Słowa kluczowe: gwałtowne wezbranie, pogórza karpackie, typologia, mała zlewnia, lokalna powódź.

\section{Wstęp}

Gwałtowne wezbrania w małych zlewniach zalicza się do zjawisk ekstremalnych, czyli takich, które odbiegają od tzw. norm wieloletnich. Wezbrania takie są istotnym problemem dla lokalnych samorządów, gdyż szkody jakie wywołują mogą stanowić znaczne obciążenie budżetu gmin. Na przykład, straty po powodzi w 2000 r. w gminie Pałecznica stanowiły prawie 18\% jej rocznego przycho-

* Praca finansowana ze środków na naukę w latach 2009-2010 jako projekt badawczy MNiSW nr N N306 039036. 
du, a powódź w zlewni Wątoka 27 czerwca 2009 r. spowodowała straty, które w przeliczeniu na $1 \mathrm{~km}^{2}$ powierzchni zlewni sięgały prawie 100 tysięcy złotych. W świetle tych danych w pełni uzasadniona jest opinia W. Parczewskiego (1960), który twierdził, że wezbrania tego typu nie są głównym źródłem strat powodziowych w Polsce jedynie dlatego, że ich zasięg terytorialny jest ograniczony.

Nie sposób wyeliminować zagrożenia związane z występowaniem gwałtownych wezbrań w małych zlewniach, a wnioski zawarte w raporcie AR4 (IPCC, 2007) wskazują, że zmiany klimatyczne mogą przełożyć się na wzrost częstości występowania silnych opadów; w powiązaniu z rosnącą presją osadniczą i niewłaściwym zarządzaniem środowiskiem może to spowodować wzrost strat wyrządzanych przez lokalne powodzie.

Jednym z dokumentów przygotowywanych w trakcie opracowania planu zagospodarowania przestrzennego terenu jest studium ochrony przeciwpowodziowej. Prawo wodne (Ustawa z dnia 18 lipca 2001) nakazuje uwzględnienie informacji zawartych $\mathrm{w}$ studium $\mathrm{w}$ dokumentach planistycznych, aby ograniczyć negatywne skutki wezbrań. W Karpatach zakresem studium objęto główne rzeki oraz ich większe dopływy. Należy jednak podkreślić, że lokalne powodzie wywołane przez pojedynczy impuls opadowy występują w zlewniach bardzo małych, na ogół o powierzchni mniejszej od $40 \mathrm{~km}^{2}$ (Bryndal, 2008). Analiza numerycznego modelu terenu z zastosowaniem GIS wskazuje, że takich zlewni w Karpatach jest kilkaset. Czy można zatem z tego zbioru wyodrębnić zlewnie szczególnie podatne na występowanie gwałtownych wezbrań? W prezentowanej pracy podjęto próbę odpowiedzi na to pytanie.

Przebieg i wielkość wezbrania uzależnione są od opadu (jego natężenia, czasu trwania, objętości) oraz parametrów zlewni (Ozga-Zielińska i Brzeziński, 1994). Badania wskazują, że właściwości zlewni wywierają decydujący wpływ na formowanie się fali wezbraniowej, zwłaszcza podczas krótkotrwałych, nawalnych opadów deszczu (Creutin i Borga, 2003; Froehlich i Słupik, 1986; Gil, 1998; Peschke i inni, 2000; Ribolzi i inni, 2000). Badania charakterystyk fizjograficznych 83 zlewni karpackich i wyżynnych, w których wystąpiły gwałtowne wezbrania dowiodły, że zlewnie te są do siebie podobne, zwłaszcza pod względem możliwości transformacji opadu w odpływ (Bryndal, 2007; 2008), a niektóre ich cechy fizjograficzne czynia je bardziej podatnymi na formowanie gwałtownych wezbrań. Jest wysoce prawdopodobne, że silne opady deszczu w zlewniach o specyficznych właściwościach fizjograficznych wywołają gwałtowne wezbranie, które może spowodować lokalną powódź. Prowadzony od kilku lat rejestr lokalnych powodzi potwierdza te wnioski. W niektórych zlewniach odnotowywane są kolejne przypadki powodzi, np.: Rzepianka - 2001, 2010, Świnka 2005,2009 . Wskazanie zlewni podatnych na formowanie gwałtownych wezbrań ułatwiłoby podjęcie działań prewencyjnych i ograniczenie strat powodziowych.

W niniejszej pracy zaprezentowano metodę umożliwiającą identyfikację małych zlewni karpackich, które są podatne na formowanie gwałtownych wez- 
brań. Praca składa się z części metodologicznej, w której przedstawiono teoretyczne podstawy metody oraz części o charakterze aplikacyjnym, opisującej jej zastosowanie na obszarze Pogórza Dynowskiego, Strzyżowskiego i Przemyskiego.

\section{Identyfikacja zlewni - charakterystyka metody}

Metoda pozwalająca wskazać zlewnie podatne na formowanie gwałtownych wezbrań jest w swych założeniach podobna do procedury doboru zlewni podobnej w metodzie analogii hydrologicznej (Brzeziński, 1996). W proponowanej procedurze wprowadzono niewielkie zmiany. Po pierwsze, pominięto charakterystyki opadowego zasilania zlewni. W znanej autorowi literaturze brak jest opracowania, w którym by przeprowadzono regionalizację Karpat dla opadów nawalnych trwających krócej niż trzy godziny, a takie przecież najczęściej powodują gwałtowne wezbrania małych cieków (Parczewski, 1960). Jako charakterystykę procesu zasilania zlewni J. Brzeziński (1996) proponuje maksymalne opady dobowe o określonym prawdopodobieństwie przewyższenia. W przypadku gwałtownych wezbrań rozwiązanie to może być jednak obarczone sporym błędem, gdyż opady o zadanym prawdopodobieństwie obliczane są z krokiem 24-godzinnym. W konsekwencji uzyskana wartość może być sumą kilku impulsów opadowych zarówno przelotnych jak i rozlewnych. Na przykład, podczas wezbrania w źródłowej części zlewni Wielopolki (25 czerwca 2009 r.), na posterunku w Brzezinach, niemal w centrum opadu, zanotowano dobową sumę opadu nieco wyższą od $95 \mathrm{~mm}$, podczas gdy obliczona ze zdjęć radarowych suma opadu, która spowodowała wezbranie, wyniosła zaledwie niewiele ponad $30 \mathrm{~mm}$ (Bryndal i inni, 2010a). Dlatego na obecnym etapie badań można przyjąć założenie, że opady nawalne mają charakter losowy i mogą pojawić się wszędzie. Druga modyfikacja polegała na przyjęciu wzorca zlewni (typu) opracowanego w toku analiz statystycznych.

Procedura pozwalająca wyodrębnić zlewnie podatne na formowanie gwałtownych wezbrań przebiegała następującymi etapami:

1) identyfikacja zlewni, w których wystąpiły gwałtowne wezbrania;

2) wybór parametrów fizjograficznych najlepiej opisujących zlewnie;

3) opracowanie bazy danych geograficznych oraz obliczenie charakterystyk fizjograficznych wybranych zlewni;

4) utworzenie macierzy informacji o zlewniach oraz ocena zróżnicowania cech fizjograficznych;

5) ocena wpływu cech fizjograficznych zlewni na formowanie gwałtownych wezbrań;

6) opracowanie wzorców zlewni podatnych na formowanie gwałtownych wezbrań;

7)identyfikacja zlewni podobnych do wydzielonych typów. 
Stosownie do zaproponowanej procedury, w pierwszej kolejności wybrano zlewnie, w których gwałtowne wezbrania opadowo-nawalne spowodowały lokalne powodzie. Sposób ich identyfikacji opisano w pracy autora (2008). Wzięto przy tym pod uwage tylko wezbrania uformowane w wyniku jednego impulsu opadowego. Ostatecznie wyselekcjonowano 85 zlewni. W kolejnym etapie wybierano parametry, które mogą być przydatne do opisu fizjografii zlewni. Podstawą były informacje z literatury (m.in. Słupik, 1973; 1981; Froehlich i Słupik, 1986; Gil, 1998; Peschke i inni, 2000; Shakya i Chander, 1998; Ribolzi i inni, 2000), przy czym uwzględniono te charakterystyki zlewni, które w istotny sposób wpływają na formowanie wezbrania. Zgodnie z zaleceniami A. Nowaka (2003) zbiór cech tak poszerzono, aby każdy badany obiekt (zlewnia) był charakteryzowany całościowo. Ostatecznie do opisu zlewni wybrano 22 charakterystyki fizjograficzne przedstawiające:

1) rozmiary i kształt zlewni: powierzchnia zlewni (A), długość maksymalna zlewni (Lmax), średnia szerokość zlewni $(B)$, wskaźnik kolistości $(C k)$;

2) cechy rzeźby zlewni: wysokość względna $(\Delta h)$, średnie nachylenie zlewni $(\psi)$, średnia wysokość zlewni liczona wg Reitza (Hśr);

3) warunki hydrologiczne: gęstość sieci rzecznej $(R z)$, średni spadek dna doliny głównej $(\psi d)$, wskaźnik alimentacji koryt $(S w)$ oraz średnią długość stoku (Ls).

Do oceny warunków hydrologicznych zlewni często stosuje się również wskaźniki: bifurkacji $(R b)$, długości cieków $(R l)$ i powierzchni zlewni $(R a)$. Opisują one strukturę sieci rzecznej zlewni i są często parametrami modeli hydrologicznych. W trakcie prowadzonych badań okazało się, że sieć rzeczna spełnia prawo liczby cieków we wszystkich badanych zlewniach, natomiast prawa długości cieków oraz powierzchni zlewni były spełnione tylko w 26 obiektach. Dlatego charakterystykę sieci rzecznej, w aspekcie ilościowej analizy zaproponowanej przez Hortona-Strahlera (Bajkiewicz-Grabowska i Magnuszewski, 2009) przeprowadzono obliczając dla wszystkich zlewni stosownie: wskaźniki bifurkacji $(R b)$, średnie długości cieków pierwszego rzędu $(L I)$, średnie powierzchnie zlewni cieków pierwszego rzędu $(A I)$ oraz wskazując najwyższy rząd cie$\mathrm{ku}(\Omega \max )$.

Użytkowanie zlewni scharakteryzowano obliczając: lesistość $(L)$ i udział jaki mają zabudowa rozproszona $(\mathrm{Zr})$, zabudowa zwarta $(\mathrm{Zz})$ oraz użytki rolne $(\mathrm{Ur})$. Obliczono również gęstość dróg (Dr) jako element, który znacząco przyspiesza dostawę wody ze stoku do dna doliny, skracając czas koncentracji i zwiększając kulminację wezbrania (Froehlich i Słupik, 1986; Słupik, 1976). Warunki geologiczno-glebowe scharakteryzowano obliczając współczynnik filtracji gleb $(k)$ (Pazdro i Kozerski, 1990).

Charakterystyki fizjograficzne zlewni obliczano według wzorów powszechnie stosowanych w hydrologii, lub wyznaczono bezpośrednio za pomocą odpowiednich modułów oprogramowania GIS, korzystając z utworzonych na potrze- 
by badań warstw tematycznych, stanowiących bazę danych geograficznych terenu. Przy ich tworzeniu korzystano z rastrowego numerycznego modelu terenu (NMT) wygenerowanego z danych wektorowych w skali 1:10 000, danych wektorowych w skali 1:50 000 oraz map glebowo-rolniczych w skalach 1:25 000 i 1:100 000 .

Z danych tych utworzono macierz informacji o zlewniach o wymiarach 22x85. Powstały zbiór danych poddano analizie statystycznej, obliczając podstawowe charakterystyki statystyczne rozkładów, w tym miary klasyczne oraz pozycyjne. Charakterystyki, których współczynniki zmienności były zbliżone lub wyższe od 50\% analizowano stosując miary pozycyjne.

W kolejnym etapie, na podstawie danych z literatury (Dobija i Dynowska, 1975; Froehlich i Słupik, 1986; Gil, 1998, 1999; Słupik, 1972, 1973, 1976, 1981) podjęto próbę oceny wpływu cech fizjograficznych badanych zlewni na formowanie gwałtownych wezbrań. Dokonano również ilościowej oceny tego wpływu obliczając parametr CN oraz czas opóźnienia (Tlag), rozumiany jako odległość pomiędzy środkiem hietogramu opadu i czasem kulminacji wezbrania (Osman i Houghtalen, 2003).

Obliczono go według wzoru:

$$
\text { Tlag }=\frac{(L \cdot 3,28 \cdot 10)^{0,8} \cdot\left(\frac{1000}{\mathrm{CN}}-9\right)^{0,7}}{1900 \cdot \sqrt{I}}
$$

gdzie: Tlag - czas opóźnienia (h); L - długość zlewni (km); I - spadek zlewni (\%); $\mathrm{CN}$ - parametr bezwymiarowy.

Parametr CN informuje o potencjalnych możliwościach transformacji opadu atmosferycznego w opad skuteczny. Przyjmuje on wartości z przedziału od 0 do 100, przy czym im wyższa wartość, tym większa część opadu zostaje zmieniona w opad skuteczny (Ozga-Zielińska i Brzeziński, 1994). Czas opóźnienia informuje o szybkości reakcji zlewni na opad.

W kolejnym etapie, stosując analizę skupień, opracowano typy zlewni podatnych na formowanie gwałtownych wezbrań. Na etapie przygotowania danych do analizy zbadano siłę i kierunek zależności statystycznych, w celu wyłączenia z macierzy informacji cech będących nośnikiem tej samej informacji (Parysek, 1982). Wykonano i przeanalizowano wykresy korelacyjne a następnie, zgodnie z podanymi w literaturze zaleceniami (Wołek, 2006) obliczono współczynnik korelacji liniowej $r$ Pearsona lub współczynnik korelacji rang $r_{s}$ Spearmana. Z analizy typologicznej wyłączono cechy, dla których współczynnik korelacji $r$ lub $r_{s}>|0,7|$, co w klasyfikacji W. Ziobronia (1977) wskazuje na średnią korelację. Ostatecznie wybrano 10 następujących cech:

- powierzchnia zlewni (A),

- wskaźnik kolistości $(C k)$, 
- średnie nachylenie zlewni $(\psi)$,

- gęstość sieci rzecznej $(R z)$,

- wskaźnik bifurkacji $(R b)$,

- średnia długość cieków pierwszego rzędu (LI),

- lesistość (L),

- zabudowa rozproszona $(\mathrm{Zr})$

- zabudowa zwarta $(\mathrm{Zz})$,

- gęstość dróg $(D r)$.

Wyznaczone zmienne poddano standaryzacji, aby wyeliminować wpływ różnych jednostek na wartość miary podobieństwa. W analizie skupień miarą podobieństwa była odległość euklidesowa, a grupowania dokonano metodą Warda (Marques de Sà, 2007). W wyniku grupowania otrzymano dendrogram, którego podział doprowadził do wyodrębnienia podzbiorów, traktowanych jako typy. Przy ich tworzeniu starano się, aby wydzielone typy różniły się od siebie, a ich liczba nie była zbyt mała. Istotność różnic badano poprzez zastosowanie nieparametrycznej analizy wariancji, z racji faktu, że nie zawsze były spełnione założenia dla wersji parametrycznej tego testu. Obliczano statystykę $\mathrm{H}$ testu Kruskala-Wallisa oraz badano jej istotność statystyczną (Wołek, 2006). Jeżeli występowały statystycznie istotne różnice pomiędzy wartościami centralnymi, wykonywano test porównań wielokrotnych (Steczkowski i Zeliaś, 1982). Pozwoliło to wskazać cechy fizjograficzne upodabniające oraz różnicujące typy. Utworzone typy zostały opisane przy użyciu klasycznych i pozycyjnych statystyk, które opisywały wartości przeciętne (średnia, mediana) oraz stopień zróżnicowania (przedziały ufności średniej, średnia pomniejszona i powiększona o wartość odchylenia standardowego, wartości minimalna i maksymalna, percentyle) poszczególnych cech fizjograficznych. Obliczone wartości pozwoliły scharakteryzować typy oraz umożliwiły wyodrębnienie zlewni, podatnych na formowanie gwałtownych wezbrań. Identyfikację przeprowadzono stosując miary zróżnicowania poszczególnych cech fizjograficznych w danym typie. Uwzględniono tylko te cechy, które różnicowały utworzone typy w sposób istotny statystycznie - powierzchnia zlewni (A), współczynnik kolistości $(C k)$ oraz średnia długość cieków pierwszego rzędu $(L I)$ zostały pominięte. Ponieważ powierzchnia zlewni nie różnicowała typów przyjęto założenie, że w procesie identyfikacji zostaną uwzględnione wszystkie zlewnie, których powierzchnia była mniejsza od największej zlewni karpackiej, w której wystąpiła lokalna powódź $(35,2$ km²). Dla tych zlewni obliczono cechy fizjograficzne i utworzono macierz informacji geograficznej o wymiarach $7 x N$, gdzie $N$ oznacza liczbę zlewni o powierzchni mniejszej od $35,2 \mathrm{~km}^{2}$. Następnie w programie GIS macierz tę powiązano ze zlewniami, przypisując im odpowiednie dane atrybutowe. Tablicę atrybutów przeszukano wykorzystując kolejne miary statystyczne opisujące zróżnicowanie cech fizjograficznych w wydzielonych typach. Były nimi: przedziały ufności średniej $\left(\bar{x}_{-0,95}, \bar{x}_{0,95}\right)$, średnia arytmetyczna pomniejszona i powiększona 
o wartość odchylenia standardowego $(\bar{x}+s, \bar{x}-s)$ oraz wartości minimalna i maksymalna cech $\left(x_{\min }, x_{\max }\right)$. Ponieważ w typologii została poddana analizie cała zbiorowość, łącznie z obserwacjami wyróżniającymi się na tle rozkładu danej cechy (tzw. obserwacje odstające i ekstremalne) (Słaby i Luszkiewicz, 2008), które wpłynęły na wartości klasycznych miar zmienności, identyfikację zlewni przeprowadzono również wykorzystując miary pozycyjne. Jako miary zmienności wykorzystano wartości: pierwszego i trzeciego kwartyla $\left(Q_{25}, Q_{75}\right)$ oraz wartości piątego, dziesiątego, dziewięćdziesiątego i dziewięćdziesiątego piątego percentyla $\left(Q_{5}, Q_{10}, Q_{90}, Q_{95}\right)$. Zastosowanie miar zróżnicowania opartych na wartościach percentyli $Q_{5}$ i $Q_{95}$ oraz $Q_{10}$, i $Q_{90}$ pozwoliło wyłączyć z analizy odpowiednio tzw. obserwacje ekstremalne i odstające. W rezultacie w procesie identyfikacji wyeliminowano te zlewnie, dla których wartość określonej cechy fizjograficznej była wyższa lub równa bądź niższa lub równa od wartości przyjętych miar zróżnicowania.

Jakość procesu identyfikacji oceniano za pomocą opracowanych przez autora wskaźników: rozłączności klasyfikacji $(W r)$ oraz zgodności (Wz). Pierwszy z nich informuje, jaka część wyodrębnionych zlewni została zaklasyfikowana wyłącznie do jednego z wydzielonych typów. Liczony jest według wzoru:

$$
W r=1-\frac{Z t}{Z o}
$$

gdzie: Wr - wskaźnik rozłączności klasyfikacji; Zt - liczba zlewni, które w procesie identyfikacji zostały zaklasyfikowane do więcej niż jednego typu; Zo - liczba zlewni wyodrębnionych ogółem.

Wskaźnik przyjmuje wartości z przedziału od 0 do 1 . Wartość 1 oznacza, że każda wyodrębniona w procesie identyfikacji zlewnia została zaklasyfikowana wyłącznie do jednego typu.

Wskaźnik zgodności informuje o tym, czy w wydzielonych zlewniach wystąpiły w przeszłości gwałtowne wezbrania, które spowodowały lokalne powodzie. Liczony jest ze wzoru:

$$
W z=\frac{Z p}{Z o}
$$

gdzie: Wz - wskaźnik zgodności; Zp - liczba zlewni wydzielonych w procesie identyfikacji, w których odnotowano powodzie; Zo - liczba zlewni wyodrębnionych ogółem.

Wskaźnik ten również przyjmuje wartość z przedziału od 0 do 1. Wartość jeden oznacza, że we wszystkich zlewniach wydzielonych w procesie identyfikacji odnotowano przypadki lokalnych powodzi. 


\begin{tabular}{|c|c|c|c|c|c|c|c|c|c|c|c|c|c|c|c|c|c|c|c|c|c|c|}
\hline \multirow{15}{*}{ 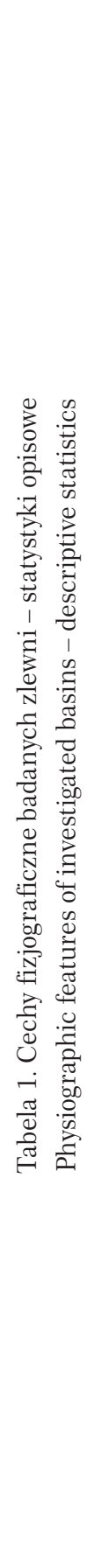 } & वे & $\begin{array}{l}0 \\
0\end{array}$ & 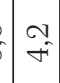 & $\begin{array}{l}0 \\
0\end{array}$ & $\overrightarrow{0}$ & \begin{tabular}{l}
0 \\
0 \\
\hdashline \\
-1
\end{tabular} & $\vec{s}$ & $\begin{array}{l}\sim \\
\infty \\
0 \\
N\end{array}$ & 0 & $\begin{array}{l}0 \\
10 \\
-1\end{array}$ & $\Rightarrow$ & $\overrightarrow{0}$ & 10 & $\stackrel{0}{-}$ & $\begin{array}{l}\mathfrak{1} \\
0 \\
0\end{array}$ & $=$ & $\begin{array}{l}F_{0} \\
\overbrace{0}\end{array}$ & $\begin{array}{l}+ \\
i\end{array}$ & $\begin{array}{l}10 \\
0\end{array}$ & 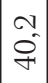 & $\Rightarrow$ & $\begin{array}{l}0 \\
0 \\
0 \\
0\end{array}$ \\
\hline & هి & $\begin{array}{l}0 \\
10 \\
\text { N }\end{array}$ & $\stackrel{10}{=}$ & $\begin{array}{l}10 \\
\infty\end{array}$ & $\tilde{0}$ & $\begin{array}{l}0 \\
i \\
0 \\
i n\end{array}$ & $\begin{array}{l}0 \\
0 \\
0\end{array}$ & $\begin{array}{l}0 \\
0 \\
0 \\
0 \\
0\end{array}$ & $\begin{array}{l}0 \\
\infty\end{array}$ & $\begin{array}{l}\tilde{f} \\
\dot{2}\end{array}$ & \begin{tabular}{|l|}
10 \\
0 \\
0
\end{tabular} & $\begin{array}{l}0 \\
0 \\
0\end{array}$ & $\overrightarrow{10}$ & $\stackrel{0}{+i}$ & $\mid \begin{array}{l}\infty \\
0 \\
0\end{array}$ & $\begin{array}{l}0 \\
0 \\
0\end{array}$ & $\begin{array}{c}0 \\
\infty \\
10 \\
1\end{array}$ & $\begin{array}{c}0 \\
10\end{array}$ & \begin{tabular}{|c|}
0 \\
$n^{2}$
\end{tabular} & $\begin{array}{l}\infty \\
\infty \\
\infty \\
1\end{array}$ & $\begin{array}{l}0 \\
10\end{array}$ & $\begin{array}{l}0 \\
0 \\
0 \\
0\end{array}$ \\
\hline & $\stackrel{10}{\sigma}$ & $\begin{array}{l}0 \\
0 \\
-1\end{array}$ & $\begin{array}{l}3 \\
\infty\end{array}$ & $\stackrel{0}{a}$ & $\tilde{0}$ & $\mid \begin{array}{c}0 \\
\vec{m} \\
m\end{array}$ & $\begin{array}{l}10 \\
0 \\
0\end{array}$ & $\begin{array}{l}10 \\
0 \\
6 \\
10\end{array}$ & $\hat{\mathrm{s}}$ & $\mid \begin{array}{l}\hat{0} \\
\hat{\sigma} \\
0\end{array}$ & $\begin{array}{l}10 \\
0 \\
0\end{array}$ & $\begin{array}{l}3 \\
0\end{array}$ & $\begin{array}{ll}10 \\
\nabla^{\prime}\end{array}$ & $\begin{array}{l}0 \\
f^{\prime}\end{array}$ & $\begin{array}{l}0 \\
0\end{array}$ & $\sigma_{0}^{+}$ & $\begin{array}{l}\overrightarrow{0} \\
\text { î }\end{array}$ & $\hat{m}$ & $\tilde{o}$ & $\begin{array}{l}F \\
10 \\
10\end{array}$ & $\stackrel{\sim}{*}$ & $\begin{array}{l}0 \\
0 \\
0 \\
0\end{array}$ \\
\hline & ミ & $\stackrel{t}{0}$ & $\begin{array}{l}0 \\
N\end{array}$ & $\stackrel{\sigma}{\sigma}$ & $\begin{array}{l}0 \\
0\end{array}$ & $\mid \begin{array}{l}0 \\
\infty \\
\stackrel{2}{0} \\
\sim\end{array}$ & $\begin{array}{l}0 \\
\infty\end{array}$ & 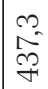 & $\stackrel{r}{\sigma}$ & $\mid \begin{array}{l}\tilde{N} \\
\underline{\sigma}\end{array}$ & $\begin{array}{l}+ \\
0 \\
0\end{array}$ & ô. & $\hat{\overbrace{}}$ & $\hat{0}$ & $\mid \begin{array}{l}10 \\
0\end{array}$ & $\begin{array}{l}3 \\
0 \\
0\end{array}$ & $\stackrel{m}{\infty}$ & $\begin{array}{c}0 \\
\text { i } \\
\end{array}$ & $\begin{array}{l}0 \\
0 \\
0\end{array}$ & $\begin{array}{l}2 \\
0 \\
0\end{array}$ & $\stackrel{N}{\sim}$ & $\begin{array}{c}0 \\
0 \\
0 \\
0 \\
0\end{array}$ \\
\hline & $\stackrel{4}{\sigma}$ & $\begin{array}{l}* \\
0\end{array}$ & 70 & $\stackrel{0}{-}$ & $\begin{array}{l}10 \\
0\end{array}$ & 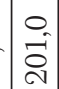 & $\stackrel{N}{N}$ & $\begin{array}{l}N \\
\infty \\
\infty \\
\approx\end{array}$ & $\vec{a}$ & 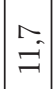 & $\overrightarrow{0}^{+}$ & $\begin{array}{l}1 \\
0 \\
0\end{array}$ & $\stackrel{0}{\aleph_{0}}$ & $\begin{array}{l}0 \\
m^{\prime}\end{array}$ & $\ddot{0}$ & $\begin{array}{l}0 \\
0 \\
0\end{array}$ & $\stackrel{N}{=}$ & $\stackrel{m}{-1}$ & $\begin{array}{l}n \\
0 \\
0\end{array}$ & $\mid \begin{array}{c}1 \\
10 \\
n \\
n\end{array}$ & $\begin{array}{l}0 \\
\aleph^{\prime}\end{array}$ & $\begin{array}{l}+ \\
0 \\
0 \\
0\end{array}$ \\
\hline & $\stackrel{\otimes}{\circ}$ & $\dot{0}$ & $\hat{n^{\prime}}$ & $\mid \begin{array}{l}\infty \\
0 \\
0\end{array}$ & $\mid \begin{array}{l}10 \\
0\end{array}$ & $\begin{array}{l}0 \\
0 \\
0 \\
n\end{array}$ & $\begin{array}{l}2 \\
0 \\
0\end{array}$ & 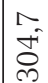 & $\stackrel{g}{-i}$ & $\begin{array}{l}\overrightarrow{5} \\
\infty\end{array}$ & $\begin{array}{l}0 \\
0 \\
0\end{array}$ & $\begin{array}{l}N \\
0 \\
0\end{array}$ & $\begin{array}{l}10 \\
0 \\
0\end{array}$ & $\begin{array}{l}0 \\
0 \\
0\end{array}$ & $\begin{array}{l}0 \\
0 \\
0\end{array}$ & $\begin{array}{l}N \\
0 \\
0\end{array}$ & $\begin{array}{l}0 \\
0 \\
-1\end{array}$ & $\begin{array}{l}n \\
0 \\
0\end{array}$ & $\begin{array}{l}0 \\
0 \\
0\end{array}$ & $\stackrel{m}{=}$ & 今. & 0 \\
\hline & 2 & 品 & $\stackrel{\infty}{=}$ & $\begin{array}{l}\infty \\
\sim\end{array}$ & $\begin{array}{l}+ \\
0\end{array}$ & $\mid \begin{array}{c}0 \\
\tilde{0} \\
0 \\
0\end{array}$ & $\vec{d}$ & $\begin{array}{l}= \\
10 \\
=10\end{array}$ & 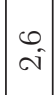 & $\mid \begin{array}{l}1 \\
\infty \\
10 \\
10\end{array}$ & $\begin{array}{l}0 \\
0 \\
0\end{array}$ & $\begin{array}{l}3 \\
0 \\
0\end{array}$ & $\begin{array}{l}0 \\
0 \\
0\end{array}$ & $\begin{array}{l}0 \\
f i\end{array}$ & $\stackrel{9}{-}$ & $\stackrel{\sigma}{-}$ & $\stackrel{n}{\sigma}$ & $\begin{array}{l}m \\
6\end{array}$ & $\begin{array}{l}10 \\
0 \\
0\end{array}$ & $\mid \begin{array}{l}10 \\
0 \\
0\end{array}$ & $\stackrel{+}{\sigma}$ & $\begin{array}{l}0 \\
\tilde{3} \\
0\end{array}$ \\
\hline & 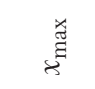 & $\begin{array}{l}\tilde{N} \\
10 \\
\infty\end{array}$ & $\left\{\begin{array}{l}\infty \\
\pm\end{array}\right.$ & $\begin{array}{l}\sim \\
n^{2}\end{array}$ & $\begin{array}{l}\infty \\
0\end{array}$ & $\mid \begin{array}{l}0 \\
0 \\
\underline{E} \\
=\end{array}$ & $\begin{array}{l}10 \\
0 \\
0 \\
\mathcal{N}\end{array}$ & 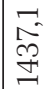 & $\begin{array}{l}\infty \\
\infty\end{array}$ & $\begin{array}{l}\overrightarrow{1} \\
\hat{6}\end{array}$ & \begin{tabular}{l|}
$\infty$ \\
0 \\
0
\end{tabular} & $\begin{array}{l}10 \\
0 \\
0\end{array}$ & $\stackrel{0}{=}$ & $\begin{array}{c}0 \\
10\end{array}$ & $\vec{a}$ & $\vec{a}$ & $\begin{array}{l}\sigma \\
\text { s. } \\
\sigma\end{array}$ & $\begin{array}{l}m \\
0\end{array}$ & $\begin{array}{l}10 \\
0\end{array}$ & $\begin{array}{l}\infty \\
\tilde{\sigma}^{\prime}\end{array}$ & $\begin{array}{l}N \\
6 \\
6\end{array}$ & $\begin{array}{l}0 \\
0 \\
0 \\
0\end{array}$ \\
\hline & 音 & $\Rightarrow$ & $\begin{array}{l}10 \\
0\end{array}$ & $\sigma_{0}^{+}$ & $\ddot{0}$ & $\mid \begin{array}{c}0 \\
m \\
=\end{array}$ & $\begin{array}{l}\alpha \\
\tilde{n}\end{array}$ & \begin{tabular}{l}
0 \\
\hdashline \\
$\infty$ \\
0 \\
$\sim$
\end{tabular} & $\stackrel{\sim}{\sim}$ & $\mid \begin{array}{c}0 \\
10 \\
10\end{array}$ & $\begin{array}{l}0 \\
0 \\
0\end{array}$ & $\overrightarrow{0}$ & $\stackrel{0}{-}$ & $\stackrel{0}{-1}$ & $\begin{array}{l}N \\
0 \\
0\end{array}$ & $\overrightarrow{0}$ & $\stackrel{0}{-}$ & -1 & 0 & $\begin{array}{l}3 \\
0 \\
0\end{array}$ & $\approx$ & $\begin{array}{l}0 \\
0\end{array}$ \\
\hline & $B^{*}$ & 10 & $\begin{array}{l}0 \\
0 \\
1\end{array}$ & $\mid \begin{array}{l}N \\
0 \\
0\end{array}$ & $\begin{array}{l}* \\
0 \\
1\end{array}$ & $\begin{array}{l}0 \\
\sigma\end{array}$ & $\begin{array}{l}0 \\
\infty\end{array}$ & $\begin{array}{l}10 \\
0\end{array}$ & $\begin{array}{l}0 \\
0\end{array}$ & $\stackrel{\sim}{-}$ & 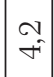 & $\stackrel{N}{f}$ & O & $\begin{array}{l}10 \\
0 \\
0\end{array}$ & $\begin{array}{l}\infty \\
10 \\
10\end{array}$ & $\begin{array}{l}0 \\
0 \\
0 \\
\text { d. }\end{array}$ & $\begin{array}{l}10 \\
0 \\
1\end{array}$ & $\begin{array}{l}n \\
0 \\
1\end{array}$ & $\stackrel{0}{\circ}$ & $\begin{array}{l}\infty \\
0 \\
1\end{array}$ & $\stackrel{N}{0}$ & $\stackrel{0}{7}$ \\
\hline & $\hat{z}^{\infty}$ & $\Rightarrow$ & $\sigma_{0}^{+}$ & $\begin{array}{l}0 \\
0\end{array}$ & $\overrightarrow{0}$ & $\hat{a}$ & $\begin{array}{l}0 \\
0 \\
0\end{array}$ & $\begin{array}{l}10 \\
0\end{array}$ & $\overrightarrow{0}$ & $\stackrel{m}{-1}$ & $\stackrel{\infty}{-}$ & $\stackrel{\infty}{-}$ & $\stackrel{g}{-}$ & $\begin{array}{l}0 \\
0 \\
0 \\
1\end{array}$ & $\vec{m}$ & $\begin{array}{l}\sigma \\
\infty\end{array}$ & $\tilde{\sigma}^{\circ}$ & $\begin{array}{l}m \\
0\end{array}$ & $\infty$ & $\begin{array}{l}n \\
0 \\
i\end{array}$ & $\begin{array}{l}n \\
0 \\
1\end{array}$ & $\begin{array}{l}m \\
0\end{array}$ \\
\hline & $>$ & $\begin{array}{l}n \\
\delta\end{array}$ & $\mid \begin{array}{l}\infty \\
\infty \\
\infty\end{array}$ & $\left\{\begin{array}{l}F_{1} \\
\stackrel{F}{F}\end{array}\right.$ & $\begin{array}{l}10 \\
10 \\
-1\end{array}$ & $\begin{array}{l}10 \\
0 \\
0\end{array}$ & $\begin{array}{l}\alpha \\
\tilde{d} \\
\tilde{m}\end{array}$ & $\underset{F}{F}$ & $\begin{array}{l}\infty \\
\infty \\
\sim\end{array}$ & $\begin{array}{l}n \\
\tilde{\theta}\end{array}$ & $\begin{array}{l}\mathcal{N} \\
\stackrel{\sim}{\sim}\end{array}$ & $\begin{array}{l}\mathcal{N} \\
\stackrel{N}{N}\end{array}$ & $\begin{array}{l}\kappa \\
\infty \\
\infty\end{array}$ & 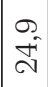 & $\begin{array}{l}\sim \\
0 \\
\mathscr{\theta}\end{array}$ & $\begin{array}{l}n \\
0 \\
0\end{array}$ & $\frac{m}{6}$ & $\begin{array}{c}m \\
10 \\
0\end{array}$ & $\begin{array}{l}1 \\
6 \\
= \\
=\end{array}$ & $\mid \begin{array}{c}0 \\
\infty \\
+ \\
+\end{array}$ & O. & 秀 \\
\hline & $\infty$ & \begin{tabular}{|l}
10 \\
00
\end{tabular} & $\begin{array}{l}\infty \\
\sim\end{array}$ & $\tilde{0}$ & $\overrightarrow{0}$ & $\mid \begin{array}{c}0 \\
+ \\
\infty \\
-1\end{array}$ & $\hat{\sigma}$ & $\begin{array}{l}m \\
\tilde{\theta} \\
\tilde{\sigma}\end{array}$ & $\begin{array}{l}10 \\
0 \\
0\end{array}$ & $\mid \begin{array}{l}0 \\
\pm \\
+\end{array}$ & $\Rightarrow$ & $=$ & $\stackrel{10}{-1}$ & $\begin{array}{l}\infty \\
0 \\
0\end{array}$ & $\begin{array}{l}m \\
0\end{array}$ & $\begin{array}{l}\infty \\
0 \\
0\end{array}$ & $\overrightarrow{\widetilde{v}}$ & $\approx$ & $\stackrel{0}{-1}$ & $\begin{array}{c}0 \\
10 \\
\mathrm{~N}\end{array} \mid$ & $\begin{array}{l}\infty \\
0\end{array}$ & $\begin{array}{l}0 \\
0 \\
0\end{array}$ \\
\hline & 18 & $\begin{array}{l}\infty \\
\stackrel{f}{f}\end{array}$ & $\stackrel{\Delta}{N}$ & $\stackrel{10}{-}$ & $\begin{array}{l}0 \\
0\end{array}$ & 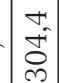 & $\begin{array}{l}10 \\
0\end{array}$ & 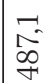 & $\begin{array}{l}\vec{a} \\
\sigma\end{array}$ & 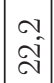 & $\begin{array}{l}F \\
0\end{array}$ & $\begin{array}{l}\mathfrak{I} \\
0\end{array}$ & $\begin{array}{l}\infty \\
\infty\end{array}$ & $\begin{array}{l}N \\
n^{2}\end{array}$ & $\begin{array}{l}0 \\
0\end{array}$ & $\begin{array}{l}* \\
0\end{array}$ & $\begin{array}{l}0 \\
0 \\
n \\
n\end{array}$ & $\begin{array}{l}10 \\
0 \\
0\end{array}$ & $\stackrel{0}{-1}$ & $\begin{array}{l}m \\
10 \\
i 0\end{array}$ & $\Rightarrow$ & $\begin{array}{c}\infty \\
10 \\
0 \\
0 \\
0\end{array}$ \\
\hline & 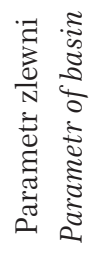 & 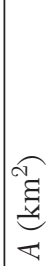 & 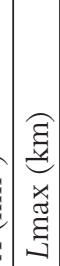 & 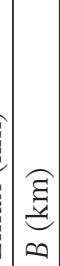 & $\frac{M}{U}$ & $\left|\begin{array}{l}\tilde{\Xi} \\
\tilde{z}\end{array}\right|$ & $\underset{\searrow}{Ð}$ & 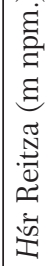 & 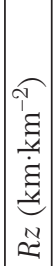 & $\begin{array}{l}2 \\
\varrho \\
z \\
\$\end{array}$ & 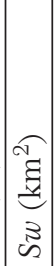 & 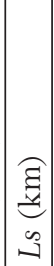 & स्रि & 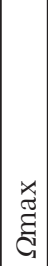 & 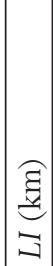 & 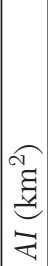 & $\stackrel{d}{a}$ & $\begin{array}{l}\hat{\varrho} \\
\vdots \\
N\end{array}$ & $\begin{array}{l}\varrho \varrho \\
\mathrm{N} \\
\mathrm{N}\end{array}$ & $\begin{array}{l}0 \\
\vdots \\
5\end{array}$ & 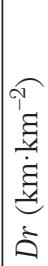 & 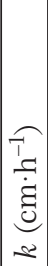 \\
\hline
\end{tabular}




\section{Wyniki}

\section{Charakterystyka zlewni}

Tabela 1 zawiera klasyczne i pozycyjne statystyki cech fizjograficznych karpackich zlewni, w których wystąpiły lokalne powodzie. Przeciętna wielkość takiej zlewni wynosi około $10 \mathrm{~km}^{2}$. Osiemdziesiąt procent z nich ma powierzchnię mieszczącą się w przedziale od 4 do $26 \mathrm{~km}^{2}$, a największa zlewnia ma nieco ponad $35 \mathrm{~km}^{2}$. Wymiary liniowe nie różnicują ich znacząco. Średnia długość badanych zlewni wynosi nieco powyżej $7 \mathrm{~km}$, przy przeciętnej szerokości $1,5 \mathrm{~km}$. Wskaźnik kolistości informuje, że zlewnie są nieco wydłużone $C K-0,6$. Zlewnie charakteryzują znaczne deniwelacje terenu oraz duże nachylenie stoków. Średnia różnica wysokości względnej wynosi $250 \mathrm{~m}$, natomiast średnie nachylenie zlewni to nieco ponad $9^{\circ}$. Sieć rzeczna zlewni jest dobrze rozwinięta. Przeciętna wartość wskaźnika bifurkacji wynosi 3,9, natomiast gęstość sieci rzecznej osiąga wartość $2,4 \mathrm{~km} \cdot \mathrm{km}^{-2}$. Cieki pierwszego rzędu mają przeciętnie $0,6 \mathrm{~km}$ długości, a jeden ciek pierwszego rzędu odwadnia średnio $0,4 \mathrm{~km}^{2}$ powierzchni zlewni. Sieć rzeczna badanych zlewni jest rozwinięta maksymalnie do cieków 5 rzędu. Średnia długość stoku jest niewielka i wynosi 0,2 km, a wskaźnik alimentacji koryt ma wartość zbliżoną do średniej powierzchni zlewni cieków pierwszego rzędu. Spadek dna doliny głównej jest bardzo duży i wynosi średnio ponad 19\%o. W strukturze użytkowania dominują użytki rolne zajmujące przeciętnie ponad 60\% powierzchni zlewni. Średnia lesistość zlewni wynosi 31\%. Powierzchnia zabudowy rozproszonej jest prawie dwukrotnie większa od zajętej przez zabudowę zwartą - odpowiednio około 3 i 1 \%. Gęstość sztucznego drenażu, jaki stanowi sieć drogowa $\left(4,1 \mathrm{~km} \cdot \mathrm{km}^{-2}\right)$, jest niemal dwu-

A - powierzchnia zlewni, Lmax - długość maksymalna zlewni, $B$ - średnia szerokość zlewni, $C k$ - wskaźnik kolistości, $\Delta h$ - wysokość względna, $\psi$ - średnie nachylenie zlewni, Hśr Reitza

- średnia wysokość zlewni npm., $R z$ - gęstość sieci rzecznej, $\psi d$ - średni spadek dna doliny głównej, $S w$ - wskaźnik alimentacji koryt, $L s$ - średnia długość stoku, $R b$ - wskaźnik bifurkacji, $\Omega$ max - najwyższy rząd cieku w zlewni, $L I$ - średnia długość cieku I rzędu w zlewni,

$A I$ - średnia powierzchnia cieku I rzędu w zlewni, $L$ - lesistość, $\mathrm{Zr}$ - zabudowa rozproszona,

$\mathrm{Zz}$ - zabudowa zwarta, $U r$ - użytki rolne, $D r$ - gęstość dróg, $k$ - współczynnik filtracji.

$\bar{x}$ - średnia arytmetyczna, $s$ - odchylenie standardowe, $V$ - współczynnik zmienności,

$W_{S}$ - współczynnik skośności, $W_{K}$ - współczynnik kurtozy, $x_{\min }, x_{\max }-$ wartości minimalne i maksymalne, $R$ - rozstęp, $Q_{10}-Q_{90}$ - percentyle, me - mediana, $Q_{R}$ - rozstęp kwartylowy. Obliczenia własne.

$A$ - area of basin, Lmax - maximum length, $B$ - average width, $C k$ - shape index, $\Delta h$ - relative height, $\psi$ - average slope gradient, Hśr Reitza - mean elevation a.s.l., $R z$ - stream network density, $\psi d$ - average slope of the main valley bottom, $S w$ - index of stream channel maintenance, $L s$ - average slope length, $R b$ - bifurcation ratio, $\Omega \max$ - the highest order stream,

$L I$ - average length of the first order stream, $A I$ - first order stream average basin area,

$L$ - forest cover, $\mathrm{Zr}$ - low density housing, $\mathrm{Zz}$ - height density housing, $U r$ - arable area,

$D r$ - road network density, $k$ - soil's permeability coefficient, $\bar{x}$ - mean, $s$ - standard deviation,

$V$ - coefficient of variability, $W_{S}-$ skewness, $W_{K}-$ kurtosis, $x_{\min }, x_{\max }-$ minimum and maximum values, $R$ - range, $Q_{10}-Q_{90}$ - percentiles, me - median, $Q_{R}$ - quartile range.

Source: This study. 
krotnie większa w porównaniu z siecią naturalnego drenażu. Pokrywa glebowa wykazuje stosunkowo niską przepuszczalność - współczynnik filtracji dla 90\% zlewni jest niższy od $0,36 \mathrm{~cm} \cdot \mathrm{h}^{-1}$.

\section{Ocena podatności zlewni na formowanie gwałtownych wezbrań}

Opierając się na analizie cech fizjograficznych zlewni, podjęto próbę oceny czy ich właściwości mogą predysponować je do formowania gwałtownych fal wezbraniowych. Spośród cech zlewni należy zwrócić uwagę na jej rozmiary. Małe zlewnie bardzo dynamicznie reagują na gwałtowne opady deszczu (Dynowska i Tlałka, 1982), ponieważ często w całości znajdują się w strefie silnych opadów. Lekko wydłużony kształt zlewni sprzyja skróceniu czasu koncentracji i zwiększa dynamikę wezbrania (Dobija i Dynowska, 1975). Badane zlewnie mają pokrywę glebową wykształconą na skałach macierzystych zasobnych we frakcje pylastą i ilastą. Są to są najczęściej gliny średnie i ciężkie oraz pyły zwykłe i ilaste, o niskim współczynniku filtracji. Takie właściwości gleb sprzyjają formowaniu się spływu powierzchniowego (Römkens i inni, 1995) powodując, że podczas intensywnych opadów deszczu tylko niewielka część wody opadowej przemieszcza się w głąb gleby (Gil, 1999). W strukturze użytkowania dominują grunty orne, na których szybciej następuje spływ powierzchniowy (Gil, 1998; Słupik, 1973). Duży udział gruntów ornych przekłada się na gęstą sieć bruzd ornych. Jak wykazały badania J. Słupika (1976), łączna długość bruzd ornych powstałych rokrocznie w wyniku zabiegów agrotechnicznych osiąga $350 \mathrm{~m}$ na 1 ha. Gęsta sieć bruzd sprzyja koncentracji spływu linijnego, o większej prędkości (Słupik, 1972). Podobnie działają drogi - znacznie przyspieszają spływ wody do dna doliny głównej, skracając czas koncentracji i zwiększając wysokość fali wezbraniowej (Froehlich i Słupik, 1986; Słupik, 1981). Badania wykazały, że mogą one odwadniać ponad 1/3 powierzchni małej zlewni pogórskiej (Kroczak, 2010).

Przeprowadzona ocena wskazała, że analizowane zlewnie mają cechy, które czynią je podatnymi na formowanie gwałtownych wezbrań. Aby to określić ilościowo, obliczono parametry: CN oraz czas opóźnienia Tlag. W odniesieniu do badanych zlewni wynoszą one średnio 82 oraz 0,9 godziny - to potwierdza, że zlewnie mają predyspozycje do formowania gwałtownych fal wezbraniowych. Jeżeli nad zlewnią o takich parametrach wystąpią silne opady deszczu, to istnieje wysokie prawdopodobieństwo, że spowodują one gwałtowne wezbranie. Otrzymane wyniki były podstawą do określenia typów zlewni podatnych na generowanie gwałtownych wezbrań.

Ryc. 1. A - Grupowanie zlewni na podstawie cech fizjograficznych;

B - Wykres osypiska z miejscem podziału dendrogramu; pbn - potok bez nazwy Opracowanie własne.

A - Groupings of basins based around physiographic features; B - Screeplots with the point of division of the agglomeration tree; pbn - creak without the name Source: own study. 


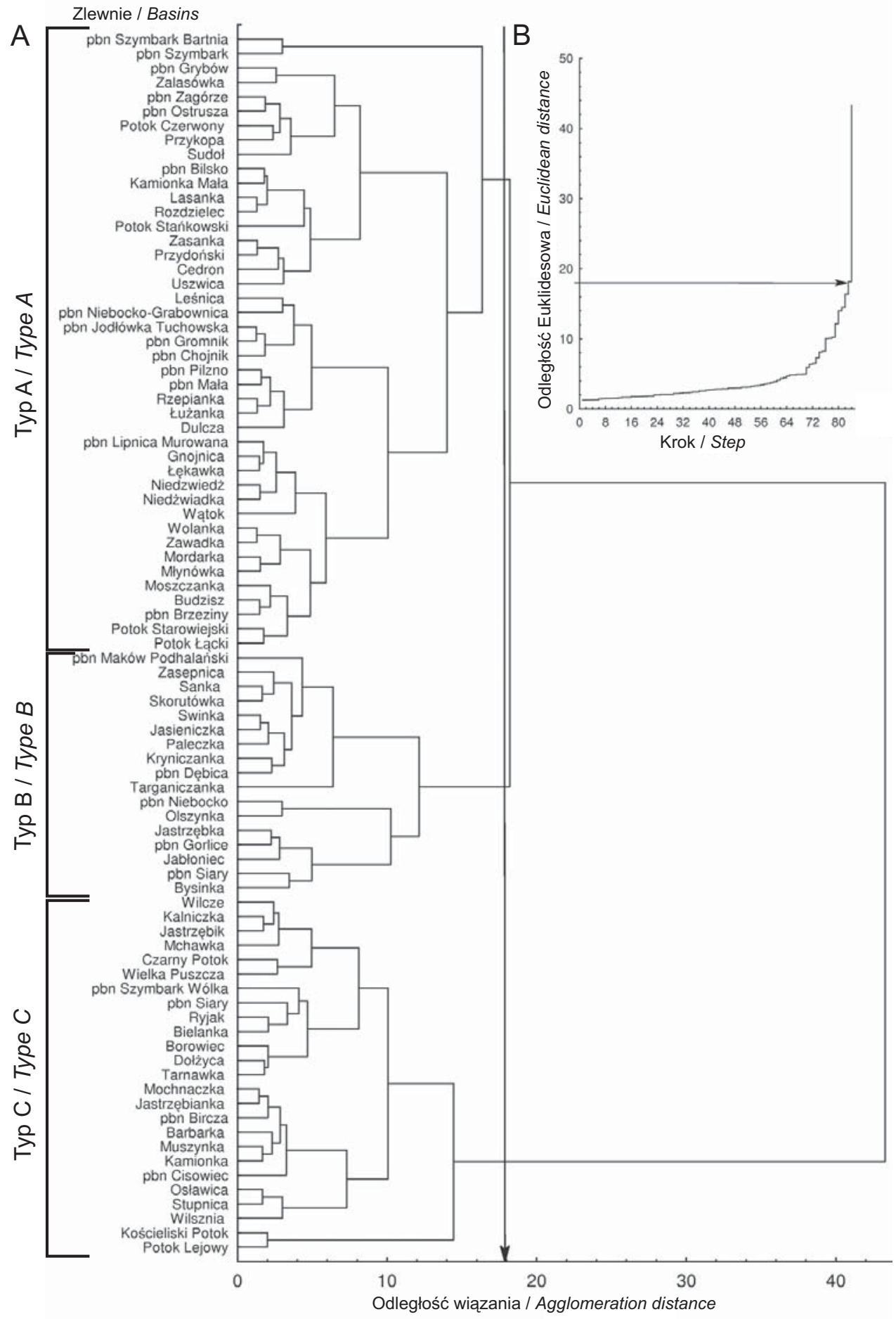




\section{Typologia zlewni}

Rycina 1A prezentuje wyniki grupowania zlewni. Zlewnie zostały pogrupowane na niskiej wartości odległości taksonomicznej - to oznacza, że są do siebie podobne. Do podziału dendrogramu zastosowano analizę wykresu osypiska (ang. screeplots), połączoną z oceną długości wiązań podczas aglomeracji (Marques de Sà, 2007). Dłuższe wiązania na dendrogramie oraz większe nachylenie linii prezentującej przebieg procesu aglomeracji na wykresie osypiska oznaczają większe różnice w wydzielonych skupieniach. Znaczące różnice między skupieniami występują powyżej osiemnastej wartości odległości taksonomicznej (ryc. 1A, B). Podział dendrogramu na tej wartości wydzielił trzy podzbiory, które traktowano jako typy. Ich charakterystyki opisowe przedstawia tabela 2. Średnie wartości cech fizjograficznych posłużyły do ich charakterystyki. Powierzchnia zlewni (A), kształt zlewni (CK) oraz średnia długość cieków pierwszego rzędu $(L I)$, nie różnicowały wydzielonych typów w sposób istotny statystycznie, więc zostały pominięte $\mathrm{w}$ dalszych analizach. Pomimo podziału dendrogramu na znacznej odległości taksonomicznej (ryc. 1A) wydzielone typy niewiele różnią się od siebie. Podobne wyniki uzyskano (Bryndal, 2009) analizując cechy fizjograficzne zlewni powodziowych położonych w różnych regionach fizycznogeograficznych Polski.

Można wskazać następujące cechy charakterystyczne typów. Typy A i B są podobne pod względem: nachylenia stoków, gęstości sieci rzecznej, lesistości i procentowego udziału zabudowy rozproszonej. W typie A wartości tych cech są nieznacznie niższe. Wydzielone typy różnią się zaś układem sieci rzecznej, udziałem zabudowy zwartej oraz gęstością dróg (tab. 2); spośród wszystkich wydzielonych typ B ma najwyższe wartości tych cech. Podsumowując można stwierdzić, że typy A i B - to zlewnie rolnicze, o znacznym nachyleniu stoków, stosunkowo małej lesistości, z rozbudowaną siecią dróg i znacznym udziałem zabudowy rozproszonej. Ponadto w typie B zaznacza się wyższy udział zabudowy zwartej.

Typ C wyróżnia się: najwyższą lesistością, najniższym udziałem zabudowy zwartej i rozproszonej oraz największym nachyleniem stoków. Układ sieci rzecznej oraz gęstość sieci drogowej upodabniają go do typu A, natomiast nachylenie stoków oraz gęstość sieci rzecznej czynią go podobnym to typu B. Ogólnie można stwierdzić, że typ $\mathrm{C}$ to zlewnia znacznie zalesiona, o bardzo dużym nachy-

$N$ - liczebność, $\bar{x}_{-0,95}, \bar{x}_{0,95}$ - przedział ufności średniej, $\bar{x}-s, \bar{x}+s$ - średnia pomniejszona i powiększona o wartość odchylenia standardowego, $Q_{5}, Q_{95}$ - percentyle. Pozostałe oznaczenia jak w tabeli 1 .'

Obliczenia własne.

$N$ - number of basin, $\bar{x}_{-0,95}, \bar{x}_{0,95}-$ mean value coefficient interval, $\bar{x}-s, \bar{x}+s-$ mean value diminished and enlarged by standard deviation, $Q_{5}-Q_{95}-$ percentiles. Other labels as in Table 1.

Source: this study. 
Tabela 2. Wybrane statystyki opisowe dla wydzielonych typów

Selected descriptive statistics of types

\begin{tabular}{|c|c|c|c|c|c|c|c|c|c|c|c|c|c|c|c|}
\hline $\begin{array}{c}\text { Typ } \\
\text { zlewni } \\
\text { Type } \\
\text { of basin }\end{array}$ & $N$ & $\bar{x}$ & $\bar{x}_{-0,95}$ & $\bar{x}_{0,95}$ & $\bar{x}-s$ & $\bar{x}+s$ & $x_{\min }$ & $x_{\max }$ & me & $Q_{5}$ & $Q_{10}$ & $Q_{25}$ & $Q_{75}$ & $Q_{90}$ & $Q_{95}$ \\
\hline \multicolumn{16}{|c|}{$A\left(\mathrm{~km}^{2}\right)$} \\
\hline A & 42,0 & 12,2 & 9,7 & 14,7 & 4,2 & 20,2 & 1,1 & 33,7 & 10,1 & 2,6 & 4,1 & 7,0 & 16,4 & 24,0 & 27,8 \\
\hline B & 17,0 & 8,6 & 6,0 & 11,3 & 3,4 & 13,8 & 1,9 & 23,3 & 7,8 & 1,9 & 3,6 & 4,6 & 11,8 & 14,1 & 23,3 \\
\hline $\mathrm{C}$ & 26,0 & 15,0 & 10,9 & 19,2 & 4,7 & 25,3 & 1,2 & 35,2 & 13,8 & 1,5 & 2,6 & 7,9 & 20,1 & 34,1 & 34,7 \\
\hline \multicolumn{16}{|c|}{$C k(-)$} \\
\hline A & 42,0 & 0,57 & 0,54 & 0,60 & 0,48 & 0,67 & 0,38 & 0,82 & 0,58 & 0,43 & 0,44 & 0,49 & 0,64 & 0,69 & 0,72 \\
\hline B & 17,0 & 0,59 & 0,55 & 0,64 & 0,50 & 0,68 & 0,43 & 0,78 & 0,57 & 0,43 & 0,48 & 0,54 & 0,65 & 0,71 & 0,78 \\
\hline $\mathrm{C}$ & 26,0 & 0,61 & 0,58 & 0,65 & 0,53 & 0,69 & 0,48 & 0,76 & 0,61 & 0,50 & 0,50 & 0,56 & 0,69 & 0,71 & 0,75 \\
\hline \multicolumn{16}{|c|}{$\psi\left({ }^{\circ}\right)$} \\
\hline A & 42,0 & 8,2 & 7,4 & 8,9 & 5,7 & 10,6 & 3,2 & 15,6 & 7,6 & 5,2 & 5,9 & 6,8 & 9,5 & 11,2 & 13,3 \\
\hline B & 17,0 & 9,8 & 8,5 & 11,1 & 7,2 & 12,3 & 5,9 & 15,5 & 10,2 & 5,9 & 6,9 & 7,9 & 11,9 & 12,4 & 15,5 \\
\hline $\mathrm{C}$ & 26,0 & 11,4 & 9,3 & \begin{tabular}{|l|}
13,4 \\
\end{tabular} & 6,3 & 16,5 & 6,2 & 26,5 & 10,0 & 6,4 & 7,0 & 8,3 & 11,8 & 16,6 & 25,7 \\
\hline \multicolumn{16}{|c|}{$R z\left(\mathrm{~km} \cdot \mathrm{km}^{-2}\right)$} \\
\hline $\mathrm{A}$ & 42,0 & 2,3 & 2,2 & 2,4 & 1,9 & 2,7 & 1,3 & 3,4 & 2,3 & 1,6 & 1,9 & 2,1 & 2,5 & 2,6 & 2,6 \\
\hline $\mathrm{B}$ & 17,0 & 2,6 & 2,3 & 2,9 & 2,1 & 3,1 & 1,9 & 3,8 & 2,7 & 1,9 & 2,0 & 2,2 & 2,8 & 3,3 & 3,8 \\
\hline $\mathrm{C}$ & 26,0 & 2,5 & 2,3 & 2,7 & 1,9 & 3,1 & 1,2 & 3,3 & 2,7 & 1,3 & 1,4 & 2,2 & 2,8 & 3,0 & 3,3 \\
\hline \multicolumn{16}{|c|}{$R b(-)$} \\
\hline A & 42,0 & 3,4 & 3,1 & 3,7 & 2,4 & 4,4 & 1,0 & 5,8 & 3,3 & 2,2 & 2,3 & 2,8 & 4,2 & 4,8 & 4,8 \\
\hline $\mathrm{B}$ & 17,0 & 5,1 & 4,0 & 6,2 & 2,9 & 7,3 & 3,0 & 11,0 & 4,5 & 3,0 & 3,2 & 3,8 & 5,0 & 9,0 & 11,0 \\
\hline $\mathrm{C}$ & 26,0 & 3,8 & 3,3 & 4,2 & 2,7 & 4,9 & 1,0 & 6,2 & 3,9 & 2,0 & 2,4 & 3,2 & 4,5 & 5,1 & 5,9 \\
\hline \multicolumn{16}{|c|}{$L I(\mathrm{~km})$} \\
\hline $\mathrm{A}$ & 42,0 & 0,6 & 0,5 & 0,7 & 0,3 & 1,0 & 0,3 & \begin{tabular}{|l|}
2,1 \\
\end{tabular} & 0,6 & 0,3 & 0,4 & 0,4 & 0,7 & 0,9 & 1,2 \\
\hline B & 17,0 & 0,5 & 0,4 & 0,5 & 0,4 & 0,6 & 0,3 & 0,7 & 0,5 & 0,3 & 0,3 & 0,4 & 0,5 & 0,7 & 0,7 \\
\hline $\mathrm{C}$ & 26,0 & 0,5 & 0,5 & 0,6 & 0,4 & 0,7 & 0,2 & 1,0 & 0,5 & 0,3 & 0,3 & 0,4 & 0,6 & 0,8 & 0,8 \\
\hline \multicolumn{16}{|c|}{$L(\%)$} \\
\hline A & 42 & 25 & 20 & 29 & 11 & 38 & 5 & 80 & 25 & 9 & 12 & 16 & 29 & 35 & 51 \\
\hline $\mathrm{B}$ & 17 & 33 & 24 & 42 & 15 & 51 & 2 & 63 & 36 & 2 & 9 & 14 & 46 & 57 & 63 \\
\hline $\mathrm{C}$ & 26 & 62 & 54 & 70 & 43 & 81 & 14 & 93 & 59 & 40 & 41 & 45 & 80 & 85 & 85 \\
\hline \multicolumn{16}{|c|}{$\mathrm{Zr}(\%)$} \\
\hline A & 42,0 & 3,2 & 2,8 & 3,6 & 2,0 & 4,4 & 0,4 & 5,3 & 3,0 & 1,7 & 1,8 & 2,4 & 4,2 & 4,8 & 5,1 \\
\hline $\mathrm{B}$ & 17,0 & 3,3 & 2,5 & 4,2 & 1,7 & 5,0 & 1,4 & 6,3 & 2,8 & 1,4 & 1,5 & 1,9 & 4,6 & 6,0 & 6,3 \\
\hline $\mathrm{C}$ & 26,0 & 1,0 & 0,5 & 1,5 & 0,0 & 2,2 & 0,0 & 5,9 & 0,7 & 0,0 & 0,1 & 0,1 & 1,3 & 1,8 & 2,9 \\
\hline \multicolumn{16}{|c|}{$\mathrm{Zz}(\%)$} \\
\hline A & 42,0 & 1,4 & 1,0 & 1,8 & 0,2 & 2,6 & 0,0 & 5,2 & 1,1 & 0,0 & 0,0 & 0,4 & 2,2 & 3,2 & 3,4 \\
\hline B & 17,0 & 4,0 & 2,8 & 5,2 & 1,7 & 6,3 & 0,8 & 9,5 & 3,2 & 0,8 & 1,8 & 2,7 & 4,7 & 8,0 & 9,5 \\
\hline $\mathrm{C}$ & 26,0 & 0,4 & 0,1 & 0,8 & $-0,4$ & 1,3 & 0,0 & 4 & 0,1 & 0,0 & 0,0 & 0,0 & 0,6 & 1,1 & 1,4 \\
\hline \multicolumn{16}{|c|}{$\operatorname{Dr}\left(\mathrm{km} \cdot \mathrm{km}^{-2}\right)$} \\
\hline $\mathrm{A}$ & 42,0 & 4,1 & 3,9 & 4,3 & 3,5 & 4,7 & 2,3 & 5,0 & 4,1 & 3,0 & 3,3 & 3,7 & 4,6 & 4,9 & 4,9 \\
\hline B & 17,0 & 4,9 & 4,5 & 5,2 & 4,2 & 5,5 & 3,7 & 6,2 & 4,9 & 3,7 & 3,8 & 4,4 & 5,3 & 5,7 & 6,2 \\
\hline $\mathrm{C}$ & 26,0 & 3,6 & 3,3 & 4,0 & 2,8 & 4,5 & \begin{tabular}{|l|}
1,7 \\
\end{tabular} & 5,7 & 3,6 & 2,4 & 2,6 & 3,1 & 4,2 & 4,6 & 4,9 \\
\hline
\end{tabular}


leniu stoków i dobrze rozwiniętej sieci dolin. Zlewnię tego typu charakteryzuje niewielki udział powierzchni uszczelnionych w wyniku zabudowy - zarówno rozproszonej, jak i zwartej - oraz najmniejsza gęstość dróg.

\section{Identyfikacja zlewni}

W celu zweryfikowania przydatności opracowanej procedury przeprowadzono identyfikację zlewni podobnych do wydzielonych typów na pogórzach: Strzyżowskim, Dynowskim i Przemyskim (ryc. 2). Obszar ten budują głównie utwory fliszowe płaszczowiny śląskiej i skolskiej. Wierzchowina Pogórzy Strzyżowskiego i Dynowskiego znajduje się na wysokości 300-450 m npm. i pocięta jest licznymi dolinkami o wypukłych lub wypukło-wklęsłych stokach, których nachylenie dochodzi do $20^{\circ}$. Wysokości względne mieszczą się $\mathrm{w}$ przedziale 50-300 m. Pokrywę glebową tworzą gleby brunatne właściwe i płowe. Na Pogórzu Przemyskim wysokości bezwzględne wzrastają w kierunku południowowschodnim od 400 do $500 \mathrm{~m}$ npm., a rzeźba nabiera wyglądu gór rusztowych (Kondracki, 1998). Wysokości względne rzadko przekraczają $300 \mathrm{~m}$. Dominują gleby brunatne kwaśne. Lasy zajmują prawie 70\% regionu. Średnie roczne temperatury powietrza mieszczą się $\mathrm{w}$ przedziale $6-8{ }^{\circ} \mathrm{C}$, podczas gdy średnie sumy opadów atmosferycznych wynoszą od 700 do $800 \mathrm{~mm}$ (Obrębska-Starklowa i inni, 1995). Według M. Stopy (1956) obszar badań znajduje się czwartej strefie burzowej, w której notuje się najwięcej tego typu zjawisk w Polsce. Średnio w lecie występuje około 25 zjawisk burzowych, przy czym w okresie letnim mogą one wystąpić średnio w ciągu 19 dni. Zakres czasowy, w którym mogą zdarzyć się gwałtowne ulewy i deszcze nawalne, trwa od 30 kwietnia do 9 września (Karwowski, 1963), a najwięcej tego typu zjawisk notuje się w czerwcu. Przyjmując jako reprezentatywne dla obszaru badań charakterystyki pluwiograficzne stacji Rzeszów można stwierdzić, że czas trwania opadów konwekcyjnych na badanym terenie nie przekracza 90 minut, a maksymalne natężenie to $35,16 \mathrm{~mm} \cdot \mathrm{h}^{-1}$ (Suligowski, 2004).

\section{Identyfikacja zlewni na podstawie cech fizjograficznych}

Wykorzystując kolejne miary zróżnicowania przeszukano bazę danych geograficznych pogórzy. Tabela 3 prezentuje liczbę zlewni wydzielonych przy zastosowaniu kolejnych miar zróżnicowania oraz wskaźniki umożliwiające ocenę jakości identyfikacji. Na etapie obliczeń cech fizjograficznych zlewni okazało się, że wiele z nich nie spełniało prawa liczby cieków Hortona. Uwzględnienie wskaźnika bifurkacji $(R b)$ spowodowałoby wyeliminowanie znacznej liczby zlewni, wśród których szukano podobnych do opracowanych typów, wobec tego wskaźnik ten został pominięty. Zastosowanie jako miar zmienności przedziałów ufności średniej nie przyniosło pozytywnego rezultatu. W opracowanej bazie nie odnaleziono zlewni, dla której wszystkie cechy były zawarte w przedziale 
$\bar{x}_{-0,95}-\bar{x}_{0,95}$ (tab. 3). Zastosowanie wartości pierwszego i trzeciego kwartyla również nie dało zadowalających wyników: Wydzielone zostało tylko 8 zlewni, podczas gdy w na analizowanym terenie gwałtowne wezbrania odnotowano w 14 zlewniach. Dlatego proces identyfikacji kontynuowano, stosując wartości minimalne i maksymalne oraz wartości percentyli $Q_{10}-Q_{90}$ oraz $Q_{5}$ i $Q_{95}$. Zastosowanie miar charakteryzujących maksymalne zróżnicowanie cech fizjograficznych opracowanych typów doprowadziło do wyodrębnienia 341 zlewni, jednakże prawie jedna trzecia z nich została zaklasyfikowana do więcej niż jednego typu $(W r=0,7)$. Otrzymano również najniższą wartość wskaźnika zgodności $(W z=0,041)$. Najlepsze wyniki uzyskano stosując wartości percentyli $Q_{10}$ i $Q_{90}$ (tab. 3). Tylko jedna zlewnia została zaklasyfikowana do więcej niż jednego typu. W podejściu tym uzyskano również najwyższą wartość wskaźnika zgodności (tab. 3). Zastosowanie percentyli $Q_{10}$ i $Q_{90}$ doprowadziło do wyodrębnienia 63 zlewni (ryc. 2). Zlewnie te obejmują najczęściej źródłowe odcinki większych rzek regionu.

Tabela 3. Liczba zlewni podatnych na generowanie gwałtownych wezbrań $(N)$ oraz wskaźniki do oceny jakości procesu identyfikacji zlewni

The number of basins prone to the generation of sudden flood waves (i.e. flash floods) and indicators which allow for evaluation of the quality of the basin identification process

\begin{tabular}{|c|c|c|c|c|c|c|}
\hline & $\bar{x}_{0,95} ; \bar{x}_{-0,95}$ & $\bar{x}+s ; \bar{x}-s$ & $x_{\min } ; x_{\max }$ & $Q_{25} ; Q_{75}$ & $Q_{10} ; Q_{90}$ & $Q_{5} ; Q_{95}$ \\
\hline$N$ & 0 & 55 & 341 & 8 & 63 & 150 \\
\hline$W r$ & - & 1 & 0,70 & 1 & 0,98 & 0,86 \\
\hline$W z$ & - & 0,109 & 0,041 & 0,125 & 0,126 & 0,080 \\
\hline
\end{tabular}

Wr - wskaźnik rozłączności klasyfikacji, Wz - wskaźnik zgodności. Pozostałe oznaczenia jak w tabeli 1.

Obliczenia własne.

$W r$-separation index, $W z$ - accordance index. Other labels as in Table 1.

Source: This study.

Wydzielono 21 zlewni typu A: większość ma powierzchnię większą od $20 \mathrm{~km}^{2}$, a cztery mniejszą od $4 \mathrm{~km}^{2}$. Zlewnie tego typu koncentrują się w środkowej i północnej części regionu (ryc. 2). Siedem zlewni zostało zaklasyfikowane do typu B - trzy o powierzchni przekraczającej $26 \mathrm{~km}^{2}$, pozostałe ponżej $4 \mathrm{~km}^{2}$. Zlewnie typu C są reprezentowane najliczniej: wydzielono ich 34, a koncentrują się w południowo-wschodniej i południowej części regionu. Typ ten grupuje zlewnie o powierzchni od 1,3 do $34,2 \mathrm{~km}^{2}$, przy czym ponad połowa ma powierzchnię większą od $10 \mathrm{~km}^{2}$. Zlewnie typu $\mathrm{C}$ wyróżnia dosyć duże nachylenie stoków - prawie w 95\% z nich średnie nachylenie przekracza $7^{\circ}$. Większość zlewni zakwalifikowanych do typów A i B, cechuje lesistość mniejsza od 30\%, w większości zlewni typu C zaś ten parametr przyjmuje wartość z przedzia- 


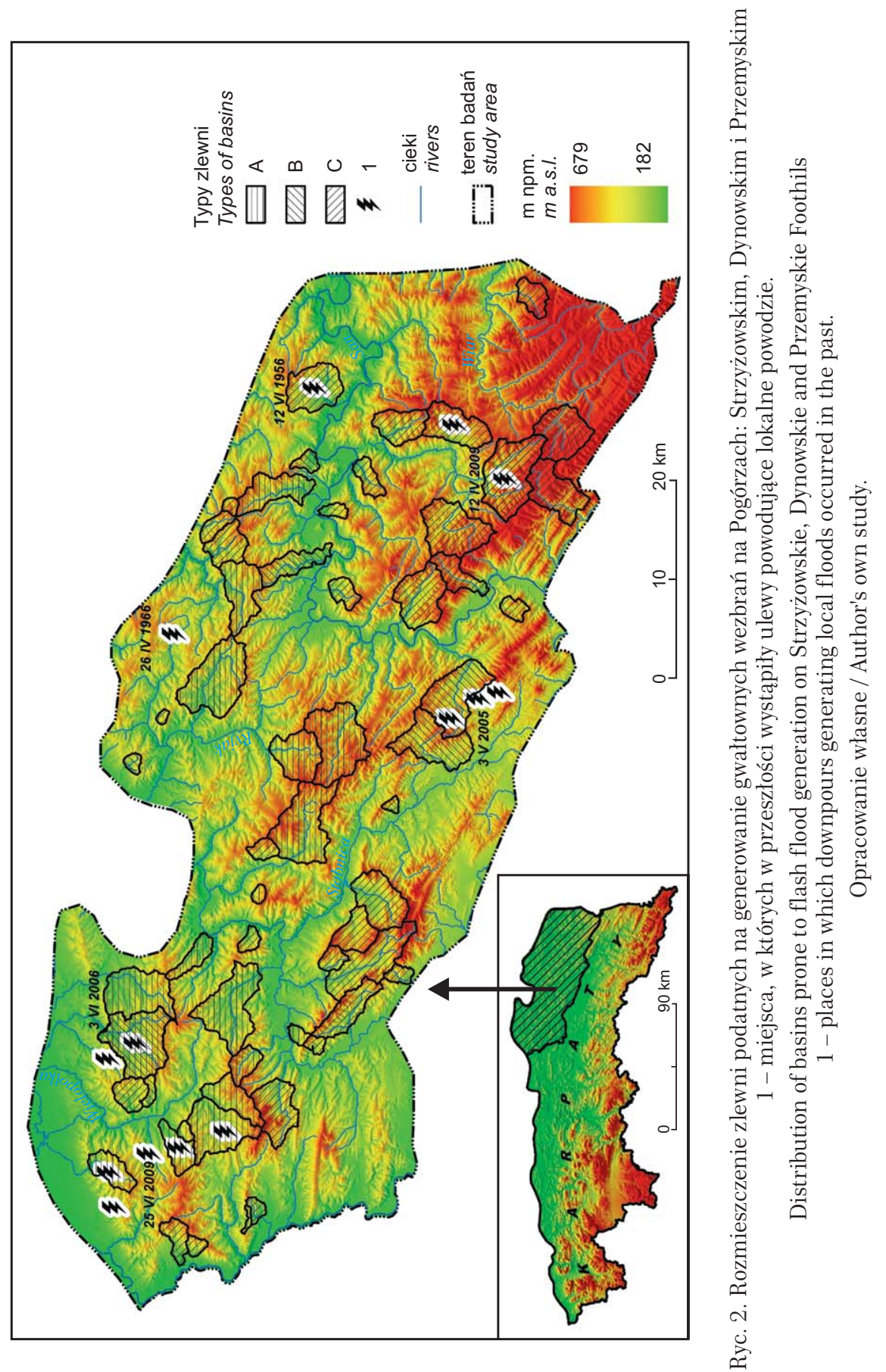


łu 40-62 \%. Ponad 90\% wydzielonych zlewni charakteryzuje stosunkowo mały udział zabudowy zwartej i rozproszonej - nie większy od 2\%. Wyodrębnione zlewnie mają dobrze rozwiniętą sieć rzeczną oraz drogową - w ponad połowie zlewni jest to odpowiednio $2,5 \mathrm{~km} \cdot \mathrm{km}^{-2}$ i $4,0 \mathrm{~km} \cdot \mathrm{km}^{-2}$. Łącznie gęstość sieci, która odprowadza wodę ze stoku w sposób zorganizowany i z dużą prędkością $\mathrm{w}$ więcej niż połowie zlewni wynosi ponad $6,5 \mathrm{~km} \cdot \mathrm{km}^{-2}$.

\section{Dyskusja}

Zaprezentowana w pracy procedura identyfikacji zlewni została oparta częściowo na założeniach metodologicznych opisujących sposób postępowania przy doborze zlewni podobnej (Brzeziński, 1996). Zlewnię podobną wyznacza się porównując określone jej charakterystyki. Przy doborze tychże charakterystyk stosowane są różne podejścia badawcze. Najczęściej opisuje się rozmiary, rzeźbę, hydrografię, użytkowanie i pokrywę glebową zlewni i takie podejście badawcze zastosowano w niniejszym opracowaniu. Jego zaletą jest możliwość uwzględnienia w opisie tych cech zlewni, które są istotne w aspekcie prowadzonych badań, wadą zaś brak możliwości przeprowadzenia ilościowej oceny wpływu tychże cech na charakterystyki hydrologiczne gwałtownego wezbrania. Nieco inne podejście przy doborze zlewni podobnej zostało wypracowane w Zakładzie Gospodarki Wodnej i Hydrologii Politechniki Warszawskiej. Jego opis zawiera między innymi praca J. Brzezińskiego (1996). Do opisu zlewni autor używa charakterystyk, które odzwierciedlają właściwości zlewni w odniesieniu do procesu transformacji opadu w odpływ. Możliwości transformacji opadu w opad efektywny dobrze charakteryzuje parametr CN używany w modelu SCS (Ozga-Zielińska i Brzeziński, 1994). W odniesieniu do wezbrań opadowych, w których dominuje odpływ powierzchniowy, cechami określającymi możliwość transformacji opadu skutecznego w odpływ mogą być zarówno dane wejściowe modelu GIUH opracowanego przez I. Rodrigeza-Iturbe i J.B. Valdesa (1979), jak i obliczone za pomoca tego modelu parametry hydrogramu jednostkowego. Zastosowanie tego podejścia w procedurze identyfikacji zlewni jest obecnie przedmiotem badań autora.

Wyznaczanie małych zlewni podatnych na formowanie gwałtownych wezbrań może mieć również znaczenie praktyczne. Należy dążyć do ograniczenia strat, spowodowanych przez takie wezbrania, a w działaniach mających na celu zmniejszenie ryzyka powodziowego trzeba brać pod uwagę stan zagospodarowania zlewni. W czasie powodzi największe są straty na terenach zabudowanych. Ich zalanie doprowadza do uszkodzenia lub zniszczenia zabudowy mieszkalnej i gospodarczej, sieci drogowej, gazowej, energetycznej oraz kanalizacyjnej. Skażeniu ulegają wody powierzchniowe i gruntowe oraz gleby. W zlewniach, w których ryzyko powodziowe jest duże, należy poprzez zastosowanie odpowiednich rozwiązań hydrotechnicznych - np. poprzez budowę suchych zbiorników retencyjnych, rozbudowę systemu małej retencji (Mioduszewski 
i Łoś, 2002) - dążyć do jak największego zredukowania gwałtownych fal wezbraniowych. Realizacja tych kosztownych działań jest ekonomicznie uzasadniona w zlewniach, w których szkody spowodowane wezbraniem przewyższałyby koszty budowy i utrzymania infrastruktury przeciwpowodziowej (Beuselinck i inni, 2000; Verstraeten i inni, 1999). W każdej zlewni należy stosować dostępne środki biernej ochrony powodziowej. S. Ziemnicki (1956) po pamiętnej powodzi w Piaskach Szlacheckich apelował, aby w małych zlewniach przestrzegać zasady „odsunięcia ludzi od wody”. W dobie narastającej presji osadniczej, także w małych zlewniach, szczególnie podatnych na występowanie lokalnych powodzi, należy sukcesywnie wyznaczać granice obszarów zalewowych dla wezbrań o określonym prawdopodobieństwie przewyższenia, tak jak to zostało wykonane $\mathrm{w}$ zlewniach większych rzek. Zgodnie z zaleceniami zawartymi w literaturze (Więzik, 2010), przepływy charakterystyczne w zlewniach niezurbanizowanych o powierzchni mniejszej od $50 \mathrm{~km}^{2}$ powinny być liczone za pomocą Formuły Opadowej (Biernat i inni, 1991). W zlewniach zurbanizowanych do tego celu powinny być zastosowane metody symulacyjne (Banasik, 2009). Powyższe metody pozwalają na obliczenie przepływów charakterystycznych o różnym prawdopodobieństwie przewyższenia, łącznie z tzw. wodą tysiącletnią $(0,1 \%)$. Badania parametrów hydrologicznych gwałtownych wezbrań (Bryndal i inni, 2008, 2010a, b; Cygan i inni, 1997; Niedbała i Soja, 1998) wykazały, że stosunkowo często notuje się przepływy maksymalne wyższe od tzw. wody tysiącletniej. Dlatego w małych zlewniach, oprócz wyznaczania zasięgu wody dla przepływów o określonym prawdopodobieństwie przewyższenia, należałoby wyznaczyć zasięg maksymalnego wiarygodnego wezbrania, zgodnie z metodyką zawartą w pracy Powodziogenność rzek pod kątem bezpieczeństwa budowli hydrotechnicznych i zagrożenia powodziowego (Ozga-Zielińska i inni, 2003). Jest to zadanie kosztowne i pracochłonne, niemniej jednak wydaje się, że wyznaczenie zasięgu maksymalnego wiarygodnego wezbrania byłoby w małych zlewniach podstawą działań pozwalających skutecznie ograniczyć straty jakie mogą spowodować gwałtowne wezbrania. Działania te w pewnym stopniu wpisują się w realizację zapisów unijnej dyrektywy w sprawie oceny ryzyka powodziowego i zarządzania nim (Dyrektywa...2007/60/WE). Oprócz prac mających na celu wyznaczenie obszarów zagrożenia powodziowego, powinny być prowadzone działania edukacyjne - zarówno dla mieszkańców jak i decydentów, którzy nie mają świadomości o zagrożeniu powodziowym w małych zlewniach. Skutkiem są błędy w planach zagospodarowania przestrzennego. Praktycznie w każdej zlewni, w której wystąpiły gwałtowne wezbrania (Bryndal i inni, 2008, 2010a, b), obserwowano nowe inwestycje - takie jak domy mieszkalne czy budynki użyteczności publicznej - zrealizowane w ciągu ostatnich 10 lat! Wykorzystuje się łatwy dostęp do infrastruktury komunikacyjnej, sieci gazowej, wodociągowej i kanalizacyjnej, ignorując niebezpieczeństwo zniszczenia lub uszkodzenia lokalizowanych inwestycji na skutek gwałtownego wezbrania. 


\section{Podsumowanie i wnioski}

W pracy przeprowadzono charakterystykę fizjograficzną małych zlewni karpackich, w których wystąpiły gwałtowne wezbrania spowodowane przez pojedynczy krótkotrwały opad deszczu. Dokonano oceny wpływu tych cech na formowanie gwałtownych wezbrań oraz opracowano wzorce (typy) zlewni podatnych na ich formowanie. Określenie typów uczyniło możliwym wskazanie na obszarze Pogórzy: Dynowskiego, Strzyżowskiego i Przemyskiego zlewni, których cechy fizjograficzne sprzyjają formowaniu tego typu wezbrań. W wydzielonych zlewniach powinny zostać podjęte działania mające na celu zmniejszenie ryzyka powodziowego poprzez stosowanie środków czynnej i biernej ochrony przeciwpowodziowej. Szczególny nacisk należy położyć na działania edukacyjne wśród mieszkańców oraz decydentów, wskazujące na zagrożenia związane z występowaniem gwałtownych wezbrań w małych zlewniach.

\section{Piśmiennictwo}

Bajkiewicz-Grabowska E., Magnuszewski A., 2009, Przewodnik do ćwiczeń z hydrologii, Wydawnictwo Naukowe PWN, Warszawa.

Banasik K., 2009, Wyznaczanie wezbrań powodziowych w małych zlewniach zurbanizowanych, Wydawnictwo SGGW, Warszawa.

Beuselinck L., Steegen A., Govers G., Nachtergaele J., Takken I., Poesen J., 2000, Characteristics of sediment deposits formed by intense rainfall events in small catchments in the Belgian Loam Belt, Geomorphology, 32, s. 69-82.

Biernat B., Bogdanowicz E., Czarnecka H., Dobrzyńska I., Fal B, Karwowski S., Skorupska B., Stachy J., 1991, Zasady obliczania maksymalnych rocznych przeptywów rzek polskich o określonym prawdopodobieństwie pojawienia się, Instytut Meteorologii i Gospodarki Wodnej, Warszawa.

Bryndal T., 2007, Transformacja opadu w odptyw w karpackich zlewniach przy wykorzystaniu GIUH, [w:] Z. Michalczyk (red.), Obieg wody w środowisku naturalnym i przeksztatconym, Wydawnictwo UMCS, Lublin, s. 117-126.

-, 2008, Parametry zlewni, w których wystapity lokalne powodzie, Annales UMCS, Sectio B, 63, s. 177-200.

-, 2009, Ocena transformacji opadu w odptyw w matych zlewniach karpackich $i$ wyżynnych, z zastosowaniem metody SCS $i$ GIUH, [w:] J. A. Jania, J. Szafraniec (red.), Ekstremalne zdarzenia meteorologiczne i hydrologiczne w Polsce, Uniwersytet Śląski, Wydział Nauk o Ziemi, Sosnowiec, s. 22-24.

Bryndal T., Cabaj W., Ciupa T., 2008, Gwattowne wezbrania matych cieków w Niecce Nidziańskiej, Przegląd Geograficzny, 80, 1, s. 127-146.

Bryndal T., Cabaj W., Suligowski R., 2010a, Hydrometeorologiczna interpretacja gwattownych wezbrań małych cieków w źródłowej części Wielopolki w dniu 25 czerwca 2009 roku, [w:] A. Magnuszewski (red.), Hydrologia w ochronie i kształtowaniu środowiska, Monografie Komitetu Inżynierii Środowiska PAN, 69, Warszawa, s. 81-91. 
Bryndal T., Cabaj W., Suligowski R., 2010b, Gwattowne wezbrania potoków Kisielina $i$ Niedźwiedź w czerwcu 2009 r. (Pogórze Wiśnickie), [w:] M. Barwiński (red.), „Obszary metropolitarne we wspótczesnym środowisku geograficznym”. 58. Zjazd Polskiego Towarzystwa Geograficznego, Oddział Łódzki PTG, Wydział Nauk Geograficznych UŁ, Łódź, s. 337-348.

Brzeziński J., 1996, Obiektywizacja doboru zlewni podobnej, Gospodarka Wodna, 4, s. $163-167$.

Creutin J.D., Borga M., 2003, Radar hydrology modifies monitoring of flash-flood hazard, Hydrological Processes, 17, s. 1-4.

Cygan M., Czulak J., Niedbała J., Niedbała J., 1997, Przeptywy kulminacyjne $i$ wielkość odptywu fali powodziowej w dorzeczu górnej Nidzicy w dniach 15/16 września 1995 roku, Dokumentacja Geograficzna, 8, IGiPZ PAN, Warszawa, s. 43-53.

Dobija A., Dynowska I., 1975, Znaczenie parametrów fizjograficznych dla ustalenia wielkości odptywu rzecznego, Folia Geographica, seriae Geographica Physica, 9, s. 77-127.

Dynowska I., Tlałka A., 1982, Hydrografia, PWN, Warszawa.

Dyrektywa Parlamentu Europejskiego i Rady 2007/60.WE z dnia 23 października 2007 r., Dziennik Urzędowy Unii Europejskiej, 228, Bruksela, s. 27-34.

Froehlich W., Słupik J., 1986, Rola dróg w ksztattowaniu sptywu i erozji w karpackich zlewniach fliszowych, Przegląd Geograficzny, 58, 1-2, s. 67-85.

Gil E., 1998, Sptyw wody i procesy geomorfologiczne w zlewniach fliszowych podczas gwattownej ulewy w Szymbarku w dniu 7 czerwca 1985 roku, Dokumentacja Geograficzna, 11, IGiPZ PAN, Warszawa, s. 85-107.

-, 1999, Obieg wody i sptukiwanie na fliszowych stokach użytkowanych rolniczo w latach 1980-1990, Zeszyty Naukowe IGiPZ PAN, 60, Warszawa.

IPCC, 2007, Climate Change 2007: Synthesis Report. Contribution of Working Groups I, II and III to the Fourth Assessment Report of the Intergovernmental Panel on Climate Change, Core Writing Team, R.K. Pachauri, A. Reisinger (red.), IPCC, Geneva, Switzerland.

Karwowski A., 1969, Opady o największym stopniu wydajności występujące w Polsce w okresie 1954-1958, Prace PIHM, 77, Warszawa.

Kondracki J., 1998, Geografia regionalna Polski, Wydawnictwo Naukowe PWN, Warszawa.

Kroczak R., 2010, Wptyw dróg polnych na ksztattowanie linii odptywu powierzchniowego na przyktadzie zlewni Zalasówki (Pogórze Ciężkowickie), [w:] T. Ciupa, R. Suligowski (red.), Woda w badaniach geograficznych, Wydawnictwo Uniwersytetu Jana Kochanowskiego, Kielce, s. 229-334.

Marques de Sà J.P., 2007, Applied Statistics Using SPSS, Statistica, Matlab and R, Springer Verlag, Berlin-Heidelberg.

Mioduszewski W., Łoś M.W., 2002, Mała retencja w systemie ochrony przeciwpowodziowej kraju, Gospodarka Wodna, 2, s. 68-73.

Niedbała A., Soja R., 1998, Odptyw z opadu nawalnego w dniu 18 maja 1996 roku w Sutoszowej, Dokumentacja Geograficzna, 11, IGiPZ PAN, Warszawa, s. 31-38.

Nowak A. (red.), 2003, Statystyka, teoria i zastosowanie, Wydawnictwo C.H. Beck, Warszawa.

Obrębska-Starklowa B., Hess M., Olecki Z., Trepińska J., Kowanetz L., 1995, Klimat, [w:] J. Warszyńska (red.), Karpaty, Wydawnictwo UJ, Kraków, s. 31-47.

Osman Akan A., Houghtalen R.J., 2003, Urban Hydrology. Hydraulics and Stormwater Quality. Engineering Application and Computer Modelling, J. Wiley and Sons, New Jersey.

Ozga-Zielińska M., Brzeziński J., 1994, Hydrologia stosowana, PWN, Warszawa. 
Ozga-Zielińska M., Kupczyk E., Ozga-Zieliński B., Suligowski R., Niedbała J., Brzeziński J., 2003, Powodziogenność rzek pod kątem bezpieczeństwa budowli hydrotechnicznych i zagrożenia powodziowego, Materiały Badawcze IMGW, seria Hydrologia i Oceanologia, 29.

Parczewski W., 1960, Warunki występowania nagłych wezbran na matych ciekach, Wiadomości Służby Hydrologicznej i Meteorologicznej, 8, 3.

Parysek J., 1982, Modele klasyfikacji w geografii, Zeszyty Naukowe UAM w Poznaniu, Seria Geografia, 31.

Pazdro Z., Kozerski B., 1990, Hydrogeologia ogólna, PWN, Warszawa.

Peschke G., Etzenberg C., Müller G., 2000, Experimental analysis of different runoff generation mechanisms, Technical Documents in Hydrology, 37, s. 203-207.

Ribolzi O., Aundrieux P., Valles V., Bouzigues R., Bariac T., Voltz M., 2000, Contribution of groundwater and overall flows to storm flow generation in the cultivated Miditerranean catchment. Quantification by natural chemical tracing, Journal of Hydrology, 233, s. 241-251.

Rodriguez-Iturbe I., Valdes J.B., 1979, The geomorphologic structure of hydrologic response, Water Resources Research, 15, s. 1409-1420.

Römkens M.J.M., Luk S.H., Poesen J.W.A., Mermut A.R., 1995, Rain infiltration into losses soil from different geographic regions, Catena, 25, s. 21-32.

Shakya N. M., Chander S., 1998, Modelling of hillslope runoff processes, Environmental Geology, 35, 2-3, s. 115-123.

Słaby T., Luszkiewicz A., 2008, Statystyka z pakietem komputerowym Statistica, teoria $i$ zastosowanie, Wydawnictwo C.H. Beck, Warszawa.

Słupik J., 1972, Sptyw powierzchniowy na stokach górskich Karpat fliszowych, Gospodarka Wodna, 8, 304, s. 290-294.

-, 1973, Zróżnicowanie spływu powierzchniowego na fliszowych stokach górskich, Dokumentacja Geograficzna, 2, IGiPZ PAN, Warszawa.

-, 1976, Zastosowanie zdjęć lotniczych w określaniu wptywu bruzd i dróg polnych na strukturę bilansu wodnego stoków górskich, Prace Naukowe Uniwersytetu Śląskiego, Fotointerpretacja w Geografii, 126, s. 31-38.

-, 1981, Rola stoku w kształtowaniu odptywu w Karpatach fliszowych, Prace Geograficzne, IGiPZ PAN, 142, Warszawa.

Soil Conservation Service, 1971, National Engineering Handbook, Section 4: Hydrology, USDA, Springfield, VA.

Steczkowski J., Zeliaś A., 1982, Analiza wariacyjna $i$ kowariancyjna w badaniach ekonomicznych, PWN, Warszawa.

Stopa M., 1956, Burze w Polsce, Prace Geograficzne, IG PAN, 34, Warszawa.

Suligowski R., 2004, Struktura czasowa i przestrzenna opadów atmosferycznych w Polsce. Próba regionalizacji, Prace Instytutu Geografii Akademii Świętokrzyskiej, Kielce, 12.

Ustawa z dnia 18 lipca 2001 r.: Prawo wodne z późniejszymi zmianami (Dz.U. 2001 Nr 115 poz. 1229).

Verstraeten G., Poesen J., 1999, The nature of small-scale flooding, muddy floods and retention pond sedimentation in central Belgium, Geomorphology, 29, s. 275-292.

Więzik B., 2010, Przeptywy maksymalne roczne o określonym prawdopodobieństwie przewyższenia w matych zlewniach niekontrolowanych, [w:] B. Więzik (red.), Hydrologia w inżynierii i gospodarce wodnej, Monografie Komitetu Inżynierii Środowiska PAN, 68, Warszawa, s. 153-166.

Wołek J., 2006, Wprowadzenie do statystyki dla biologów, Wydawnictwo Naukowe Uniwersytetu Pedagogicznego w Krakowie, Kraków. 
Ziemnicki S., 1956, Skutki deszczu nawalnego we wsi Piaski Szlacheckie pod Krasnymstawem, Gospodarka Wodna, 11, s. 476-480.

Ziobroń W., 1977, Metody statystyczne, Wydawnictwo Politechniki Krakowskiej, Kraków.

[Wpłynęło: październik 2010; poprawiono: styczeń 2011 r.]

TOMASZ BRYNDAL

\author{
THE IDENTIFICATION OF SMALL DRAINAGE BASINS \\ PRONE TO FLASH-FLOOD CREATION \\ (AS EXEMPLIFIED BY THE DYNÓW, STRZYŻÓW AND PRZEMYŚL FOOTHILL AREAS)
}

Extremely heavy convective rainfall over a short period of time is the most frequent cause of flash flooding in small rivers (Parczewski, 1960). The hydrological parameters to the flood wave generated in this way depend on rainfall characteristics and river basin features such as area, relief, geomorphology, land use, and geology (OzgaZielińska and Brzeziński, 1994). In turn, certain parameters of a basin may predispose it to flash-flood generation, and the identification of the drainage basins in question is thus important, since it may allow the flood hazard to be reduced. The goals of the work described here were thus: (1) to present a method that may be used in identifying drainage basins in the Carpathians that are prone to flash flood creation; (2) to identify river basins of these kinds in the areas of the Strzyżów, Dynów, and Przemyśl foothill.

In the event, the investigation of 85 Carpathian drainage basins affected by flash flooding (Table 1) did indeed point to marked susceptibility to flash-flood generation. The typical Carpathian river basin in which flash flooding tends to appear is found to be small in area $\left(A \approx 10 \mathrm{~km}^{2}\right)$, with a lightly extended shape $(\operatorname{Lmax} \approx 7 \mathrm{~km}, B=1.5, C k$ $\approx 0.6)$, significant relative height $(h \approx 250 \mathrm{~m})$ and a steep slope gradient $\left(\psi \approx 9^{\circ}\right)$. The river network is mostly dense $\left(D \approx 2.4 \mathrm{~km} \cdot \mathrm{km}^{-2}\right)$ and well-developed $(R b \approx 3.9)$.

On average, first-order streams were of $0.6 \mathrm{~km}$ in length, draining $0.4 \mathrm{~km}^{2}$ of catchment area. Usually, the river network was developed to fifth-order streams, while the average value for slope length reached $0.2 \mathrm{~km}$. Catchments were deforested to a considerable extent $(L \approx 31 \%)$, and arable areas were slightly dominant ( $U r \approx 60 \%)$. The road network, which plays a crucial role in flood wave generation (Froehlich and Słupik, $1986)$, was very well-developed. Road network density $\left(D \approx 4.1 \mathrm{~km} \cdot \mathrm{km}^{-2}\right)$ was almost twice as high as river network density. Soil cover permeability was very low. Ninety per cent of basins had coefficients of soil permeability below $0.36 \mathrm{~cm} \cdot \mathrm{h}^{-1}$. Values for lag time and the $\mathrm{CN}$ parameter have confirmed that basins were prone to flash-flood generation. Average values for those parameters have reached 82 and $0.9 \mathrm{~h}$ respectively.

The above results served in the description of types of basin in the Carpathians that are prone to flash-flood generation. Table 2 presents statistical parameters for these different identified types. Types A and B bring together catchments on which arable lands dominate. These are markedly deforested, with steep slopes and a dense road network. Low-density housing also occupies a significant part of the basin area. Moreover, a high value for high-density housing was characteristic for type B. Type $\mathrm{C}$ in turn comprises 
catchments that are more forested, with a very steep slope, a dense and well-developed river network, and impermeable areas occupying a small part.

The identification process relied on comparison between statistically derived diversity measures for types and physiographic features of natural basins. Several diversity measures were applied, but the best results were obtained when values for the $Q_{10}$ and $Q_{90}$ percentiles were used (Table 3). Sixty-three river basins identified were characterized by the spatial distributions presented in Fig. 2. They covered the headwaters of larger river basins in the region. Type A, represented by 21 catchments, included four covering less than $4 \mathrm{~km}^{2}$ and others usually larger than $20 \mathrm{~km}^{2}$ - all were concentrated in the central and northern parts of the study area (Fig. 2). Type B, represented by 7 watersheds, included three of more than $26 \mathrm{~km}^{2}$ and others covering less than $4 \mathrm{~km}^{2}$. Type $\mathrm{C}$ brings together 34 basins concentrated in the southern and south-eastern part of the region, with areas in the range $1.3-34.2 \mathrm{~km}^{2}$ (albeit with more than half larger than $10 \mathrm{~km}^{2}$ ). The catchments identified had steep slopes, almost 95\% of them with gradients of more than $7^{\circ}$. Most basins assigned to types A and B had forest cover below $30 \%$, while type $\mathrm{C}$ basins had 40-62\% cover. More than 90\% of the catchments were less than $2 \%$ built-up in settlements. Basins did have very well-developed river and road networks, however, the values for these parameters exceeding 2.5 and $4.0 \mathrm{~km} \cdot \mathrm{km}^{-2}$ respectively in the case of more than half of the basins studied. More than half of the basins delineated had densities of the surface drainage network in excess of $6.5 \mathrm{~km} \cdot \mathrm{km}^{-2}$.

Alongside its scientific value, the identification of basins prone to the generation of flash floods has a practical aspect. Information about the spatial distribution of such river basins may allow flood damage to be mitigated. Flood risk maps with boundaries of the maximum probable flood needing to be prepared for the catchments concerned. Activities promoting an awareness of the flood hazard among citizens and decisionmakers should also be taken up. 
http://rcin.org.pl 